\title{
Preparation of an Alcoholic Beverage from Muskmelon (Cucumis melo L. var. Punjab Sunheri)
}

\author{
Jyoti Bala ${ }^{1}$ and Gurvinder Singh Kocher ${ }^{2 *}$ \\ Department of Microbiology, Punjab Agricultural University, Ludhiana-141004, India \\ *Corresponding author
}

\section{A B S T R A C T}

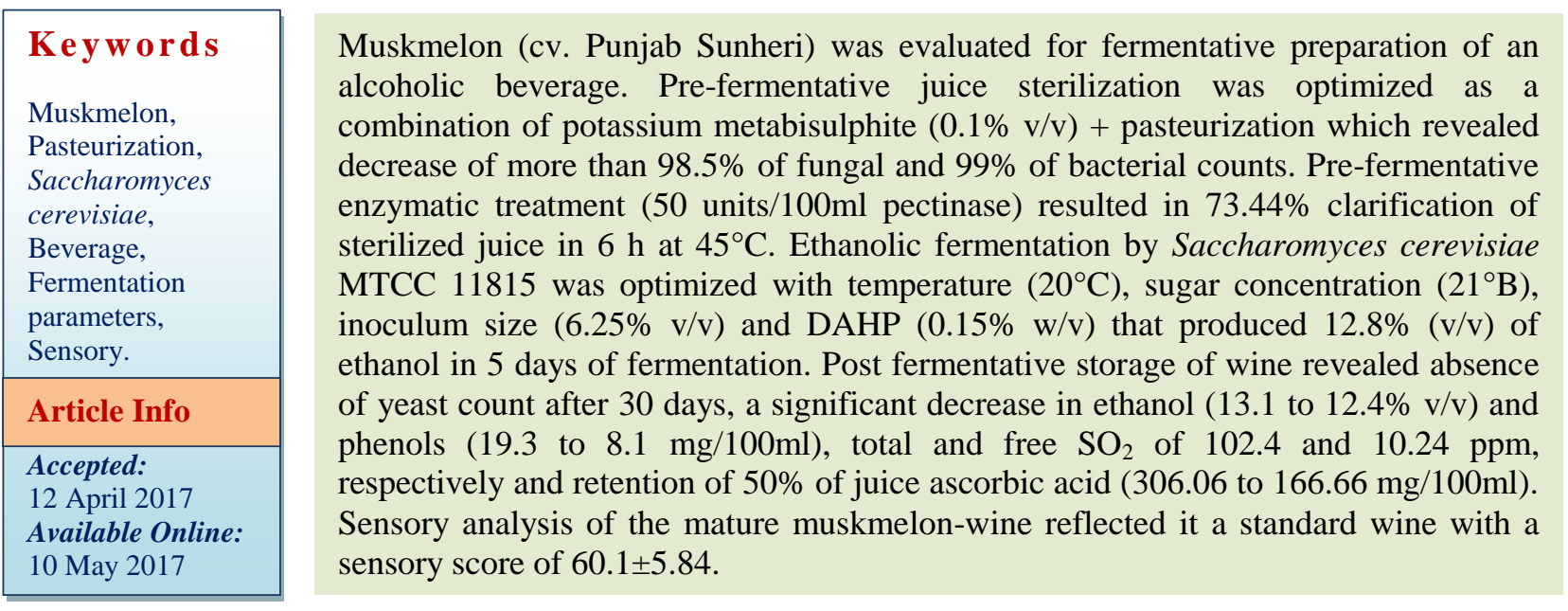

\section{Introduction}

Fruit wines are undistilled nutritive alcoholic beverages produced by fermentation of fruit juices either spontaneously or by known strain of microorganisms mainly a yeast species so as to develop a particular quality of wine. Among fruits, grapes have been used as the main raw material in the production of wines hence its name. However, a number of alternate fruits have been found suitable for wine production such as mango, banana, guava, apple, pear etc (Joshi and Attri, 2005; Durate et al., 2010). Among these, muskmelon (Cucumis melo L.) (Family Cucurbitaceae) is one of the important fruits in India. Muskmelon, a sweet fruit of Punjab containing more than $90 \%$ water is also enriched with phytochemicals, making it a suitable substrate for wine preparation (Lester, 1997). This fruit is taken as table fruit and has a low shelf life even under refrigerated conditions (Dunlap et al., 1990). However, Muskmelon with a TSS of 10-13\% has a juice recovery of $85 \%$ but its juice $\mathrm{pH}$ of 5.7-6.7 makes it susceptible to bacterial contamination (Kim et al., 2006). Hence there is an imperative need to increase shelf life of this fruit while retaining its useful components. Further, muskmelon juice is 
hazy due to presence of pectin that makes a turbid wine after fermentation. Therefore it is imperative to standardize pre-fermentative and fermentative conditions for producing a good muskmelon-wine for which many statistical experimental design methods have been suggested. Earlier, we employed RSM and CCD to optimize fermentation conditions for production of muskmelon-wine as brix, temperature, inoculum size and DAHP concentration of $15^{\circ} \mathrm{B}, 20^{\circ} \mathrm{C}, 6.25 \%(\mathrm{v} / \mathrm{v})$ and $0.15 \%(\mathrm{w} / \mathrm{v})$ which produced an ethanol of $8.9 \%(\mathrm{v} / \mathrm{v})$ (Jyoti, 2014). Hence for producing a wine of atleast $10 \%(\mathrm{v} / \mathrm{v})$, the present study was conducted on producing melon wine by increasing the brix of wort using commercial sugar (sucrose) and evaluated its effect on quality of wine produced.

\section{Materials and Methods}

Muskmelon (Cucumis melo L.) cv. Punjab Sunheri was procured from Department of Vegetable Science, Punjab Agricultural University, Ludhiana. Healthy fruits were washed with boiled and cooled water containing $0.01 \%$ of KMS (Potassium metabisulphite). Juice was extracted by mechanical pressing followed by sieving and subjected to a combination of KMS $(0.1 \%$ $\mathrm{w} / \mathrm{v})+$ Pasteurization $\left(60-65^{\circ} \mathrm{C}\right.$ for $15-20$ min) treatment. Thereafter, the juice was treated enzymatically with pectinase (50 units $/ 100 \mathrm{ml}$ ) at $45^{\circ} \mathrm{C}$ for 2-6 hours (Kocher and Pooja, 2011). The periodic samples were taken aseptically and evaluated for total viable count and \% clarification.

\section{Experimental design for ethanolic fermentation of sugar chaptalized muskmelon juice}

The granulated refined sugar was procured from local market and its syrup was prepared in small quantity of melon juice @ 250g/250 $\mathrm{ml}$. The latter was used to chaptalize melon juice to raise the brix at 5 levels viz., 15 to $23^{\circ} \mathrm{B}$ and the above pretreated muskmelon juice $(500 \mathrm{ml})$ was taken in $1000 \mathrm{ml}$ capacity Erlenmeyer flasks which were previously washed with boiled water and cotton plugged. The juice was fermented by inoculating a starter culture of Saccharomyces cerevisiae MTCC 11815 at already optimized fermentation conditions of brix, temperature, inoculum size and DAHP concentration of $15^{\circ} \mathrm{B}, 20^{\circ} \mathrm{C}, 6.25 \%(\mathrm{v} / \mathrm{v})$ and $0.15 \%(\mathrm{w} / \mathrm{v})$, respectively (Jyoti, 2014). The periodic samples were taken and analyzed for TSS (glass brixometer), $\mathrm{pH}$ (hand $\mathrm{pH}$, Henna meter) and ethanol content (Caputi et al., 1968). The fermentation efficiency of different treatments was calculated as:

Fermentation efficiency: Actual ethanol produced (v/v) $\times 100$ Theoretical ethanol (v/v)

Theoretical Ethanol \% (v/v) = Sugar utilized $(\%) \times 0.64$

Sugar utilized $=$ Available sugar- Sugar present after fermentation

\section{Post-fermentative treatments}

The bottles containing prepared muskmelonwine were stored at $15^{\circ} \mathrm{C}$ and lees /debris was allowed to settle and the cleared wine was racked by siphoning. The racking was repeated after every 15 days till there was no further settling of debris. The clarified wine was stored in glass bottles (washed earlier with boiling water and capped) for up to 3 months. The refrigerated stored wine was analyzed for total microbial count using plate count method on GYE media, ethanol (\% $\mathrm{v} / \mathrm{v})$, total phenols $(\mathrm{mg} / 100 \mathrm{ml})$ and ascorbic acid $(\mathrm{mg} / 100 \mathrm{ml})$ at different periods of time for up to 3 months. The clarified wine was also subjected to sensory analysis on the basis of Modified Davis Card (Amrine et al 1980) by a panel of 10 semi-trained judges. 
The free and total sulphur dioxide in the stored wine was observed in muskmelon wine by Ripper Method (Ripper, 1898). The qualitative analysis of muskmelon wine with respect to amino acids carried out by Thin Layer Chromatography (Silica gel, Solvent system- Chloroform: Methanol: Acetic acid65:25:4) was also studied (tera.chem.ut.ee;www.reachdevices.com).

The standard amino acids were also run on thin Layer Chromatograms and compared with those of muskmelon-wine.

\section{Results and Discussion}

\section{Physicochemical characteristics of the juice}

Physicochemical characteristics of the extracted juice from the Punjab Sunheri variety revealed a low brix (TSS $6.2{ }^{\circ} \mathrm{B}$ ), acidity $(0.14 \% \mathrm{w} / \mathrm{v}), \mathrm{pH}(6.4)$, brix -acid ratio (43.69), ascorbic acid (306.06 mg/100ml) and phenols (35.1 mg/100ml). Earlier Pandey et al., (2008) reported variety specific TSS of $13.45,10.55,9.48$ and $10.18 \%$ in Kashi Madhu, NDM-18, NDM-21 and Punjab Sunheri, respectively. Similarly Parveen et al., (2012) observed a TSS of $8-13 \% \mathrm{w} / \mathrm{v}$ and a total titratable acidity of $0.13-0.21 \%$ in muskmelon.

Augustin et al., (1988); Beaulieu and Lee (2007) reported a $\mathrm{pH}$ range of 5.25-6.79 in muskmelon during storage of fruits harvested at maturity stage and a titrable acidity of 0.15 $0.27 \%$, respectively. As the brix-acid ratio was low, it was adjusted by chaptalizing sugar alongwith addition of citric acid $(0.8 \mathrm{~g} / \mathrm{L})$ to adjust $\mathrm{pH}$ of the wort.

\section{Pre-fermentation treatment}

The results presented in table 1 revealed that the microbial count of fresh juice was high on nutrient agar (NA) than glucose yeast extract agar (GYE) media and thus more susceptible to bacterial contamination. KMS+ Pasteurization treatment of juice reduced microbial count to $1.0 \times 102$ on $\mathrm{NA}$ and $2.8 \times 102$ on GYE which corresponded to a significant decrease of more than $98.5 \%$ of fungal counts and more than $99 \%$ of bacterial counts. In literature, there are no such reports (to be the best of our knowledge) on treatment of muskmelon juice for reducing native microflora. However, there are reports in other fruits and vegetables, e.g. Pasteurization for carrot and kunun-zaki (Kun et al., 2008, Egbere et al., 2009, respectively) and pasteurization in combination with preservatives like KMS and sodium benzoate in Sapota (Hiremath and Rokhade, 2012).

The KMS-pasteurization treated juice was subjected to pectinase action (50 units/100ml) at $45^{\circ} \mathrm{C}$ for $2-6 \mathrm{~h}$ that revealed $73.44 \pm 0.261 \%$ clarification (due to pectin hydrolysis) in $6 \mathrm{~h}$ of incubation at $45^{\circ} \mathrm{C}$ (Table 1). Further, there was more decrease in number of bacterial and fungal counts which showed that during pectinase treatment, the juice did not undergo any microbial spoilage. Earlier, we optimized pectinase treatment (50 units/ $100 \mathrm{ml}$ ) at a temperature of $45^{\circ} \mathrm{C}$ for $6 \mathrm{~h}$ for $47 \%$ clarity of guava juice (Nikhanj and Kocher, 2015). Saxena et al., (2012) also standardized $0.09 \%(\mathrm{w} / \mathrm{w})$ of pectinase for clarification of watermelon juice.

\section{Ethanol fermentation of pretreated watermelon juice}

The pectinase clarified muskmelon juice was chaptalized with sugar at five different brix levels of $15,17,19,21$ and $23^{\circ} \mathrm{B}$ and fermented using RSM optimized conditions of $20^{\circ} \mathrm{C}, 6.2 \% \quad(\mathrm{v} / \mathrm{v})$ and $0.15 \% \quad(\mathrm{w} / \mathrm{v})$ of temperature, inoculums size and DAHP, respectively (Bala and Kocher, 2012). 
Table.1 Effect of pre-fermentation treatment of muskmelon juice

\begin{tabular}{cc}
\hline Growth Media & cfu/ml of post treated muskmelon juice \\
\hline Treatment & KMS +Pasteurization \\
\hline Nutrient agar $(\mathbf{c f u} / \mathbf{m l})$ & $1.0 \times 10^{2}$ \\
\% decrease & 99.5 \\
& $2.8 \times 10^{2}$ \\
Glucose yeast extract $(\mathbf{c f u} / \mathbf{m l})$ & 98.6 \\
\% decrease & \\
\hline
\end{tabular}

\begin{tabular}{|c|c|c|c|}
\hline$\underset{\downarrow}{\text { Time }}(\mathrm{h}) \backslash \mathrm{cfu} / \mathrm{ml}$ & \multicolumn{3}{|c|}{$\begin{array}{c}\text { Plate count (Nutrient agar (NA)/ Glucose yeast extract (GYE) after Pectinase treatment (50 } \\
\text { units } / 100 \mathrm{ml}, 6 \mathrm{~h}, 45^{\circ} \mathrm{C} \text { ) }\end{array}$} \\
\hline \multicolumn{4}{|l|}{$\mathbf{0}$} \\
\hline NA & $2.5 \times 10^{2}$ & $2.2 \times 10^{2}$ & $1.0 \times 10^{2}$ \\
\hline GYE & $3.0 \times 10^{2}$ & $3.5 \times 10^{2}$ & $2.8 \times 10^{2}$ \\
\hline \multicolumn{4}{|l|}{2} \\
\hline NA & $1 \times 10^{1}$ & $4 \times 10^{1}$ & $2 \times 10^{1}$ \\
\hline GYE & $4 \times 10^{1}$ & $2 \times 10^{2}$ & $1.2 \times 10^{2}$ \\
\hline$\%$ Clarification & $72.21 \pm 0.190$ & $71.67 \pm 0.07$ & $71.55 \pm 0.296$ \\
\hline \multicolumn{4}{|l|}{4} \\
\hline NA & $2 \times 10^{1}$ & $5 \times 10^{1}$ & $4 \times 10^{1}$ \\
\hline GYE & $3 \times 10^{1}$ & $3 \times 10^{1}$ & $5 \times 10^{1}$ \\
\hline$\%$ Clarification & $72.44 \pm 0.155$ & $72.35 \pm 0.777$ & $71.82 \pm 0.268$ \\
\hline \multicolumn{4}{|l|}{6} \\
\hline NA & $4 \times 10^{1}$ & $6 \times 10^{1}$ & $5 \times 10^{1}$ \\
\hline GYE & $4 \times 10^{1}$ & $1 \times 10^{1}$ & $3 \times 10^{1}$ \\
\hline$\%$ Clarification & $73.44 \pm 0.261$ & $72.03 \pm 0.735$ & $71.75 \pm 0.325$ \\
\hline
\end{tabular}

*Plate counts in untreated Punjab Sunheri juice were $2.0 \times 10^{4} \mathrm{cfu} / \mathrm{ml}$ in NA and $1.4 \times 10^{4} \mathrm{cfu} / \mathrm{ml}$ in GYE.

$*$ Scale of treatment $=100 \mathrm{ml}$

$\%$ decrease $=$ Initial count - Final count $\times 100$

Initial count 
Table.2 Effect of sugar chaptalization on ethanol content of pretreated muskmelon juice

\begin{tabular}{|c|c|c|c|c|c|c|}
\hline $\begin{array}{c}\text { Substrate } \\
\text { concentration } \\
(\boldsymbol{\%})\end{array}$ & $\mathbf{p H}$ & $*$ Brix $\left({ }^{\circ} \mathbf{B}\right)$ & $* *$ Days & $\begin{array}{c}\text { Ethanol } \\
\mathbf{\%}(\mathbf{v} / \mathbf{v})\end{array}$ & $\begin{array}{c}\text { Reducing } \\
\text { sugar } \\
(\mathbf{m g} / \mathbf{1 0 0 m})\end{array}$ & $\begin{array}{c}\text { Fermentation } \\
\text { efficiency } \\
(\mathbf{\%})\end{array}$ \\
\hline $\mathbf{1 5}(\mathbf{C o n t r o l})$ & $3.2 \pm 0$ & $2.5 \pm 0.707$ & 3 & $8.9 \pm 0.141$ & $0.335 \pm 0.035$ & 92.7 \\
\hline $\mathbf{1 7}$ & $3.2 \pm 0$ & $3.4 \pm 0.565$ & 4 & $9.85 \pm 0.071$ & $0.425 \pm 0.049$ & 90.5 \\
\hline $\mathbf{1 9}$ & $3.2 \pm 0$ & $4.0 \pm 0$ & 5 & $11.5 \pm 0.353$ & $0.5 \pm 0.014$ & 94.5 \\
\hline $\mathbf{2 1}$ & $3.0 \pm 0$ & $4.5 \pm 0.707$ & 5 & $12.8 \pm 0.353$ & $0.59 \pm 0.021$ & 95.2 \\
\hline $\mathbf{2 3}$ & $3.0 \pm 0$ & $6.0 \pm 0$ & 5 & $12.5 \pm 0.424$ & $1.0 \pm 0.212$ & 84.9 \\
\hline $\mathbf{C D}(\mathbf{5 \%})$ & & 0.775 & & & \\
\hline
\end{tabular}

*With Hydrometer, brix was zero in all different substrate concentrations treatments

**Days for fermentation

Volume of wort : $300 \mathrm{ml}$, Inoculum size: $6.25 \% \mathrm{v} / \mathrm{v}$, DAHP: $0.15 \% \mathrm{w} / \mathrm{v}$, Temperature: $20^{\circ} \mathrm{C}$ 
Table.3 Validation of Optimized fermentation conditions of Punjab Sunheri

\begin{tabular}{|c|c|c|c|c|c|c|c|c|}
\hline \multirow{2}{*}{$\begin{array}{c}\text { Fermenta } \\
\text { tion time } \\
\text { (Days) }\end{array}$} & \multicolumn{2}{|c|}{ Brix $\left({ }^{\circ} \mathbf{B}\right)$} & \multicolumn{2}{|c|}{ pH } & \multicolumn{2}{|c|}{$\begin{array}{l}\text { Reducing sugar } \\
(\mathrm{mg} / 100 \mathrm{ml})\end{array}$} & \multicolumn{2}{|c|}{ Ethanol (\% v/v) } \\
\hline & $\begin{array}{c}\text { Pectinase } \\
\text { treated }\end{array}$ & Control* & $\begin{array}{c}\text { Pectinase } \\
\text { treated }\end{array}$ & Control* & $\begin{array}{c}\text { Pectinase } \\
\text { treated }\end{array}$ & Control* & $\begin{array}{c}\text { Pectinase } \\
\text { treated }\end{array}$ & Control* \\
\hline $\mathbf{0}$ & $21.0 \pm 0.13$ & $21 \pm 0.20$ & $3.8 \pm 0.071$ & $3.8 \pm 0.071$ & $985 \pm 7.07$ & $985 \pm 6.45$ & $0.0 \pm 0.06$ & $0.0 \pm 0.03$ \\
\hline 1 & $19.0 \pm 0.15$ & $20 \pm 0.71$ & $3.7 \pm 0.0$ & $3.8 \pm 0.0$ & $785 \pm 7.77$ & $869.01 \pm 6.81$ & $0.525 \pm 0.16$ & $0.32 \pm 0.08$ \\
\hline 2 & $16.5 \pm 0.71$ & $16.9 \pm 0.07$ & $3.7 \pm 0.071$ & $3.5 \pm 0.071$ & $645 \pm 5.65$ & $800.9 \pm 4.21$ & $3.8 \pm 0.14$ & $2.96 \pm 0.11$ \\
\hline 3 & $12.5 \pm 0.71$ & $14 \pm 0.71$ & $3.5 \pm 0.071$ & $3.4 \pm 0.0$ & $61 \pm 1.41$ & $577.6 \pm 1.89$ & $9.15 \pm 0.07$ & $4.2 \pm 0.14$ \\
\hline 4 & $9.0 \pm 0.05$ & $12.1 \pm 0.14$ & $3.3 \pm 0.0$ & $3.0 \pm 0.071$ & $32 \pm 1.41$ & $402.02 \pm 0.29$ & $9.9 \pm 0.14$ & $4.4 \pm 0.14$ \\
\hline 5 & $0.0 \pm 0.10$ & $8.2 \pm 0.35$ & $3.2 \pm 0.071$ & $3.0 \pm 0.0$ & $4.8 \pm 0.92$ & $311.2 \pm 0.35$ & $12.7 \pm 0.353$ & $5.1 \pm 0.21$ \\
\hline 6 & - & $5 \pm 0.07$ & - & $3.0 \pm 0.0$ & - & $22.8 \pm 0.57$ & - & $6.83 \pm 0.13$ \\
\hline 7 & - & $0 \pm 0.04$ & - & $3.0 \pm 0.0$ & - & $11.2 \pm 0.14$ & - & $8.2 \pm 0.14$ \\
\hline
\end{tabular}


Table.4 Effect of storage time on microbiological and physicochemical properties of Muskmelon wine cv. Punjab Sunheri

\begin{tabular}{cccc}
\hline \multirow{2}{*}{$\begin{array}{c}\text { Storage } \\
\text { Time (Days) }\end{array}$} & \% Ethanol (v/v) & Phenol (mg/100ml) & Total yeast count (cfu/ml) \\
\cline { 2 - 4 } 0 & $13.1 \pm 0.212$ & $19.3 \pm 0.019$ & $3.2 \times 10^{2}$ \\
15 & $12.9 \pm 0.282$ & $18.1 \pm 0.036$ & $1.9 \times 10^{2}$ \\
30 & $12.7 \pm 0.353$ & $15.2 \pm 0.048$ & $6 \times 10^{1}$ \\
45 & $12.6 \pm 0.494$ & $13.9 \pm 0.036$ & 0.0 \\
60 & $12.4 \pm 0.565$ & $8.1 \pm 0.022$ & 0.0 \\
\hline $\begin{array}{c}\text { CD (5\%) } \\
\text { Sensory }\end{array}$ & $\mathrm{CD}$ (days) -0.195 & $\mathrm{CD}($ days $)-1.56$ & \\
score & $\mathrm{CD}($ ethano)- 0.309 & $\mathrm{CD}($ phenol)-2.46 & \\
\hline
\end{tabular}

Total $\mathrm{SO}_{2}=102.4 \mathrm{ppm}$

Free $\mathrm{SO}_{2}=10.24 \mathrm{ppm}$

Ascorbic acid $=166.66 \mathrm{mg} / 100 \mathrm{ml}$ (Ascorbic acid in juice: $306.06 \mathrm{mg} / 100 \mathrm{ml}$ ) 
The results presented in table 2 revealed that all the treatments had significantly different ethanol production and the juice having a Brix level of $21^{\circ} \mathrm{B}$ produced a maximum of $12.8 \%$ $(\mathrm{v} / \mathrm{v})$ ethanol in 5 days of fermentation. Elsewhere, studies on muskmelon fermentation have revealed low ethanol contents of $4.2 \%$ and $6.5 \%$, respectively (Hernandez-Gomez et al., 2005; Shukla et al., 1991). However, muskmelon juice if chaptalised with sugar content of $21 \%, \mathrm{pH}$ of 3.8 at $24^{0} \mathrm{C}$ produced muskmelon wine with ethanol content of $11 \%(\mathrm{v} / \mathrm{v})$.

The authors optimized $21 \%$ \& $22 \%(\mathrm{w} / \mathrm{v})$ as initial sugar concentration to produce $11 \%$ $(\mathrm{v} / \mathrm{v})$ ethanol in muskmelon-wine and watermelon-wine production, respectively (Yang, 2007; Yang, 2008). Such reports for alternate fruits like pineapple, mango, grapes, guava etc. are also available. Earlier, we also optimized 9.0 and $5.0 \%$ (v/v) inoculum sizes of Saccharomyces cerevisiae for wine production from guava and grapes, respectively (Kocher and Pooja, 2015).

Therefore, the optimized studies of fermentation parameters revealed sugar concentration of $21^{\circ} \mathrm{B}$, temperature $20^{\circ} \mathrm{C}$, inoculum level $6.25 \%(\mathrm{v} / \mathrm{v})$ and DAHP $0.15 \%$ (w/v) as optimum for 'Punjab Sunheri' fermentation. These conditions were also validated on pretreated juice at $5 \mathrm{~L}$ scale. The results presented in table 3 revealed that pectinase treated and untreated wort fermentation at $5 \mathrm{~L}$ validated the optimized fermentation conditions with ethanol production of $12.7 \pm 0.353 \%(\mathrm{v} / \mathrm{v})$ and $8.2 \%$ $(\mathrm{v} / \mathrm{v})$, respectively.

The $\mathrm{pH}$ of fermenting juice decreased from 3.8 to 3.2 and 3.8 to 3.0 and reducing sugars decreased from $985 \pm 7.07$ to $4.8 \pm 0.92$ $\mathrm{mg} / 100 \mathrm{ml}$ in 5 days of fermentation and 985$11.2 \mathrm{mg} / 100 \mathrm{ml}$ in 7 days of fermentation, respectively.

\section{Post- fermentation treatment}

The results of different physicochemical and microbiological parameters studied during racking (Table 4) revealed that the yeast cells were undetectable after 30 days of storage in muskmelon wine. Ethanol content though significantly decreased over the storage period of 60 days to a final \% ethanol (at 60 days) of $12.4 \%(\mathrm{v} / \mathrm{v})$ was still sufficient to be named a wine. Total phenols also decreased significantly from 19.3 to $8.1 \mathrm{mg} / 100 \mathrm{ml}$ during storage and ascorbic acid decreased from 306.06 to $166.66 \mathrm{mg} / 100 \mathrm{ml}$ during storage period.

Earlier, literature reports up to $90 \%$ decrease of anthocyanins with no change in flavanol content of red wines during storage. It was also reported that the decrease in phenols stabilized after 90-120 days of storage (Zafrilla et al., 2003) and volatile compounds in red wine were significantly decreased by increasing storage time (Perez-Prieto et al., 2003). Decrease in total phenols upto 6 months of storage in white wine was also observed by Kallithraka et al (2009). The storage of wine in oak wood barrels for a month improved its quality and led to the reduction in undesirable components such as n-propanol, n-butanol, iso-butanol, isoamyl alcohols (Soni et al., 2009).

The free and total sulphur dioxide in the stored wine was also observed. The muskmelon-wine contained $102.4 \mathrm{ppm}$ of total $\mathrm{SO}_{2}$ and $10.24 \mathrm{ppm}$ of free $\mathrm{SO}_{2}$ at 60days of storage against maximum limits of $200 \mathrm{ppm}$ and $50 \mathrm{ppm}$, respectively. It has been reported that free sulfur dioxide levels higher than $25 \mathrm{ppm}$ severely bleached the color of red muscadine wine and lessened browning in high $\mathrm{pH}$ wine only (Sims and Moris, 1984). High $\mathrm{SO}_{2}$ levels also lessened browning of wine stored at $20^{\circ} \mathrm{C}$, but not at higher storage temperatures. The muskmelon- 
wine samples were also subjected to sensory analysis to find out their acceptability among the semi-trained tasting panelists. The wine prepared from Punjab Sunheri variety of muskmelon under the optimized conditions having $12.7 \pm 0.353 \%$ ethanol (v/v) was found to be of standard quality with a mean score of 60.1 55.84 (Table 4). The semi-trained panelists however differed significantly in their taste opinions.

Earlier, it has been reported that melon wine with initial sugar concentration of $25^{\circ} \mathrm{B}$ presented the best attributes of color, smell, taste, limpidity and appearance on the basis of sensory evaluation (Padin et al., 2012). It was also observed that muskmelon wine was light yellow, good in mouth feel, luster-transparent and unique in flavor (Yang, 2007).

The qualitative analysis of wine with respect to amino acids carried out by Thin Layer Chromatography revealed amino acid spots showing Rf values of $0.12,0.146,0.18,0.32$, $0.46,0.56$, respectively. The standard amino acids were also run on Thin Layer Chromatograms and compared with the spots of wine Thin Layer Chromatograms. Based on comparison and the available literature (tera.chem.ut.ee;www. reachdevices.com), the $\mathrm{Rf}$ values were designated to the presence of histidine, arginine, lysine, proline, threonine, methionine, alanine, valine, tyrosine and tryptophan in muskmelon-wine (http://tera.chem.ut.ee).

The present study thus revealed preparation of an alcoholic beverage from muskmelon var. Punjab Sunheri. Besides optimization of prefermentation, fermentation and postfermentation parameters, the muskmelon wine was tested for the quality parameters for up to 60 days. It may be concluded that muskmelon-wine is a nutritive alcoholic beverage having phenols and amino acids.

\section{Acknowledgement}

The authors thank Dr. V.K Vashisht, Vegetable Breeder, Department of Vegetable Science for providing muskmelon fruit for this research.

\section{References}

Amerine, M., Berg, H.W., Kunkee, R.E., Ough, C.S., Singletone, V.L. and Webb, A.D. 1980. Technology of wine making, 4th edn, U.S.A. AVI Publ Co, West Port, Connecticut, 523-547.

Augustin, M.A., Osman, A., Azudin, M.N. and Mohamed, S. 1988. Physicochemical changes in muskmelons (Cucumis melo L.) during storage. Pertanika, 11: 203-209.

Bala, J., Kocher, G.S. and Vashisht, V.K. 2012. Optimization of pre-fermentative treatments for clarification of muskmelon (Cucumis melo L.) Juice. Crop Improvement, ISSN 0256-0933, 1197-1198.

Beaulieu, J.C. and Lea, J.M. 2007. Quality changes in cantaloupe during growth, maturation and in stored fresh-cut cubes prepared from fruit harvested at various maturities. J. American Soc. Horticulture Sci., 132: 720-728.

Bertolini, M.C., Ernandes, J.R. and Laluce, C. 1991. New yeast strains for alcoholic fermentation at higher sugar concentration. Biotechnol. Lett., 13: 197-202.

Caputi, A.J., Ueda, M. and Brown, T. 1968. Spectrophotometric determination of ethanol in wine. Am. J. Enol. Vitic., 19: 160-165.

Duarte, W.F., Dias, D.R., Oliveira, M.J., Teixeira, J.A., Silva, J.D. and Schwan, R.F. 2010. Characterization of different fruit wines made from cacao, cupuassu, gabiroba, jaboticaba and umbu. Food Sci. Technol., 30: 1-9. 
Dunlap, J.R., Lingle, S.E. and Lester, G.E. 1990. Ethylene production in netted muskmelon subjected to postharvest heating and refrigerated storage. Horticulture Sci., 25: 207-209.

Egbere, O.J., Pam, K.V., Adesheyan, K.D., Kadir, A.T. and Oyero, S.K. 2009. Effects of pasteurisation on survival patterns of microorganisms and vitamin C retention in Kunun-zaki. Afr. J. Biotechnol., 8: 6603-6607.

Hernandez-Gomez, L.F., Ubeda, J., GarciaRomero, E. and Bronies, A. 2005. Comparative production of different melon distillates: chemical and sensory analysis. Food Chem., 90: 115-125.

Hiremath, J.B. and Rokhade, A.K. 2012. Preparation and preservation of sapota juice. Int. J. Food Agri. Vet. Sci., 2: 8791.

Joshi, V.K. and Attri, D. 2005. Panorma of research and development of wines in India. Ind. J. Sc. Ind. Res., 64: 9-18.

Kallithraka, S., Salacha, M.I. and Tzourou, I. 2009. Changes in phenolic composition and antioxidant activity of white wine during bottle storage: Accelerated browning test versus bottle storage. $J$. Food Chem., 113: 500-505.

Kaur, S., Sarkar, B.C., Sharma, H.K. and Singh, C. 2009. Optimization of enzymatic hydrolysis pretreatment conditions for enhanced juice recovery from guava fruit using response surface methodology. Food Bioprocess Technol., 2: 96-100.

Kim, T., Kim, S., Kim, J. and Lee, S. 2006. Properties of oriental melon wine developed by utilizing rice wine fermentation method. Agric. Chem. Biotechnol., 49: 125-130.

Kun, S., Rezessy-Szabo, J.M., Nguyen, Q.D. and Hoschke, A. 2008. Changes of microbial population and some components in carrot juice during fermentation with selected
Bifidobacterium strains. Process Biochem., 43: 816-821.

Lester, G. 1997. Melon (Cucumis melo L.). Fruit Nutritional Quality and Health Functionality. Hort. Technol., 7: 222227.

Mosqueda-Melgar, J., Raybaudi-Massilia, R.M. and Martin-Belloso, O. 2007. Influence of treatment time and pulse frequency on Salmonella enteritidis, Escherichia coli and Listeria monocytogenes populations inoculated in melon and watermelon juices treated by pulsed electric fields. Int. J. Food Microbiol., 117: 192-200.

Nikhanj, P. and Kocher, G.S. 2015. Fermentative Production of GuavaWine (Psidium Guajava L) Using S. cerevisiae MTCC 11815. Curr. Nutr. Food Sci., 11(1): 21-30.

Padín, C., Goitia, J., Hernández, R. and Leal, I. 2012. Remove from marked Records Chemical and sensory characterization of artisanal wine from melon (Cucumis melo L. var. reticulatus Naud., cv. ovation), Revista Venezolana de Ciencia y Tecnología de Alimentos 3, 270-284.

Pandey, S., Rai, M., Prasanna, H.C. and Kalloo, G. 2008. 'Kashi Madhu': A new muskmelon cultivar with high total soluble solids. HortSci., 43: 245-246.

Parveen, S., Ali, M.A., Asghar, M., Khan, A.R. and Salam, A. 2012. Physicochemical changes in muskmelon (Cucumis melo L.) as affected by harvest maturity stage. J. Agri. Res., 50: 249-260.

Perez-Prieto, L.J., Lopez-Roca, J.M. and Gomez-Plaza, E. 2003. Differences in major volatile compounds of red wines according to storage length and storage conditions. J. Food Comp. Anal., 16: 697-705. 
Ripper, M. 1898. Die Schwelflige Saure im Wein und deren Bestimmung. J. Praia. Chem., 46: 428-473.

Saxena, D., Sabikhi, L., Chakraborty, S.K. and Singh, D. 2014. Process optimization for enzyme aided clarification of watermelon juice. $J$. Food Sci. Technol., 51(10): 2490-2498.

Shukla, K.G., Joshi, M.C., Saraswati, Y. and Bisht, N.S. 1991. Jamal wine making: Standardization of methodology and screening of cultivars. J. Food Sci. Technol., 28: 142-144.

Sims, C.A. and Morris, J.R. 1984. Effects of $\mathrm{pH}$, sulfur dioxide, storage time, and temperature on the color and stability of red muscadine grape wine. Am. J. Enol. Viti., 35: 35-39.
Soni, S.K., Bansal, N. and Soni, R. 2009. Standardization of conditions for fermentation and maturation of wine from Amla (Emblica officinalis Gaertn.). Nat. Prod. Rad., 8: 436-444.

Yang Sheng-ao, 2007. Study on brewing technology of muskmelon wine. China Patent, Tongren, Abstr., 554300.

Yang Sheng-ao. 2008. Study on fermentation conditions of watermelon peel wine. China Patent, Tongren, Abstr, 554300.

Zafrilla, P., Morillas, J., Mulero, J., Cayuela, J.M., Martínez-Cachá, A., Pardo, F. and López Nicolás, J.M. 2003. Changes during storage in conventional and ecological wine: phenolic content and antioxidant activity. J. Agric. Food Chem., 51: 4694-4700.

\section{How to cite this article:}

Jyoti Bala and Gurvinder Singh Kocher. 2017. Preparation of an Alcoholic Beverage from Muskmelon (Cucumis melo L. var. Punjab Sunheri). Int.J.Curr.Microbiol.App.Sci. 6(5): 1373-1383. doi: https://doi.org/10.20546/ijcmas.2017.605.148 